\title{
University and community-based medical education
}

\section{大学と地域医療の関係性}

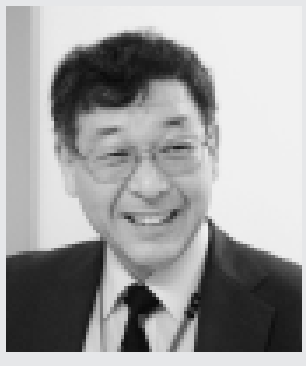

1981 年東京慈恵会医科大学卒業. 1983 年大学院単位取得 (医学博士). 解 剖学講座講師を経て, 1999 年医学教育研 究室助教授, 2001 年教授, 2007 年教育セ ンター長.

1997 年 Harvard-Macy Program for Physician Educators 修了. 現在, 日本 医学教育学会副会長, 編集委員長, 全国 医学部長病院長会議広報委員長, 医学教 育振興財団運営委員, 編集委員長.

1996 年の東京慈恵会医科大学カリ キュラム改革に参加し, その後, 慈恵医 大で 1 年次福祉体験実習, 2 年次重症心 身障害児療育体験実習，地域子育て支援 体験実習, 3 年次在宅ケア実習, 5 年次家 庭医実習 (以上必修科目), プライマリケ ア・選択学外臨床実習（選択科目）など の地域医療カリキュラムを作ってきた. また，訪問看護師対象の聴診セミナーや 地域医療者のための教育ワークショップ を実施している．大学附属病院では多職 種連携ワークショップであるチーム医療 構築ワークショップの責任者でもある.

\section{福島 統}

Community-based Medical Education という言葉がある. 特定機能 病院である大学附属病院のみで医学教育を完遂するわけにはいかない. 大学は積極的に地域という教育力を医学教育に中に取り込み, 急性期疾 患だけでなく，慢性疾患患者の生活支援や家族支援という医療ニーズを 学生に示して行くことが必要である。地域という臨床教育の「場」を取 り込むためには, 大学が地域医療者と連携を取っていく体制作りが求め られる。また, 地域といっても地域中核病院, 診療所だけではなく, 訪 問看護ステーション, 福祉施設, 高齢者・子ども・若い母親支援などの 地域団体, さらには特別支援学校も含め多くの学習の「場」が存在する. 大学はただ単に, 地域の教育力を利用するだけではなく, 大学が主体性 をもって地域の教育力を支えていく時代になっている，大学には地域で 求められている様々な「智」がある。学生教育に関わる地域医療者に, 教育能力開発のためのワークショップを提供したり, 診療技能際教育 コース, 生涯学習コースを提供したりすることで大学・地域連携を築く ことは, 大学附属病院と地域医療との間の医療連携にも良い影響を与え るであろう。医師養成は大学だけの仕事ではない，医師養成は大学と地 域とで育てていくものである，大学はもっと開放的になって，地域で学 生を指導する地域医療者をカリキュラム改革にも参加してもらい, 大学 のための医師養成ではなく, 地域との連携の中での国民のための医師養 成を行っていかなければならない.

\section{文 献}

1) Boaden, N. ; Bligh, J. Community-based Medical Education. Arnold, London, 1999.

2) Whitehouse, C. ; Roland, M. ; Campion, P. Teaching Medicine in the Community. A Guide for Undergraduate Education, Oxford University Press, 1997.

福島 統（ふくしま おさむ）

東京慈恵医科大学教育センター長

（＝ 105-8461 東京都港区西新橋 3-25-8 e-mail : fukushima@jikei.ac.jp） 